\title{
Molecular genetic analysis of a thioredoxin gene from Thiobacillus ferrooxidans
}

\author{
Rosamund E. Powles, Shelly M. Deane and Douglas E. Rawlings
}

Department of Microbiology, University of Cape Town, Rondebosch 7700, South Africa

\author{
Author for correspondence: Douglas. E. Rawlings. Tel: +27 21 6503261. Fax: +27 216504023 . \\ e-mail: doug@molbiol.uct.ac.za
}

Keywords: Thiobacillus ferrooxidans, thioredoxin, molecular cloning

\section{INTRODUCTION}

Thiobacillus ferrooxidans is an autotrophic, chemolithotrophic, Gram-negative bacterium that obtains its energy by oxidizing $\mathrm{Fe}^{2+}$ to $\mathrm{Fe}^{3+}$ or reduced sulfur compounds to sulfuric acid. It is highly acidophilic and grows optimally within the $\mathrm{pH}$ range $1 \cdot 5-3 \cdot 5$. Much interest has been shown in $T$. ferrooxidans because of its use in industrial mineral processing and because of its unusual physiology.

Thioredoxins are small, heat-stable, ubiquitous proteins that serve as a source of electrons in numerous metabolic processes (Holmgren, 1989). The oxidized form of thioredoxin contains a disulfide bridge that is reversibly reduced by NADPH and thioredoxin reductase (Moore $e t$ al., 1964). The reduced form is a strong protein disulfide oxidoreductase that is involved in the reduction of ribonucleotide reductase, an essential enzyme in DNA synthesis (Laurent et al., 1964), and in the reduction of enzymes that reduce sulfate and methionine sulfoxide (Gonzalez Porqué et al., 1970). Thioredoxin is also a highly efficient disulfide reductase of wide specificity, catalysing many dithiol-disulfide redox reactions. A characteristic of thioredoxins is the presence of the well-

The GenBank/EMBL accession number for the sequence reported in this paper is U20361. conserved redox active site, -Trp-Cys-Gly-Pro-Cys(Holmgren, 1968).

Thioredoxin has been identified as an essential subunit of T7 phage DNA polymerase (Mark \& Richardson, 1976). It forms a stable 1:1 complex with the T7 polymerase gene 5 protein, increasing the processivity of the enzyme several hundredfold (Tabor et al., 1987). Thioredoxin is also required for the growth of the filamentous phages $\mathrm{M} 13, \mathrm{f1}$ and $\mathrm{fd}$, where the role of thioredoxin is different from that of phage T7. Although the exact mechanism is not fully understood, thioredoxin is thought to interact with the gene 1 protein and to be involved in filamentous phage assembly (Russel \& Model, 1986).

In plant cells, thioredoxin is involved in the regulation of enzymes of carbon dioxide fixation. During photosynthesis, electrons are passed from chlorophyll to ferredoxin and then to thioredoxin via ferredoxin-thioredoxin reductase (Buchanan, 1980). The reduced thioredoxin then activates enzymes such as fructose-1,6-bisphosphatase and NADP-malate dehydrogenase. All plant tissues analysed have two or more thioredoxin species (Buchanan et al., 1979). As an obligate autotroph, an efficient fructose-1,6bisphosphatase is essential for the growth of $T$. ferrooxidans and two genes encoding this enzyme have been cloned from the bacterium (Kusano et al., 1991). Whether thioredoxin plays a role in the regulation of these enzymes is still not known. Thioredoxin may be used in other roles 
associated with the habitat of T. ferrooxidans. For example, thioredoxin is a cofactor used for the detoxification of arsenic by the ArsC protein (Ji \& Silver, 1992) found on several plasmids and the chromosome of E. coli (Carlin et al., 1995). When growing in arsenopyrite ores, $T$. ferrooxidans is able to tolerate high concentrations of arsenic, although it has not yet been shown that arsenic resistance is due to a mechanism similar to that of ArsC.

In this paper we report the isolation of the T. ferrooxidans $\operatorname{tr} x A$ gene, its characterization, and the ability of the thioredoxin to complement $E$. coli $\operatorname{tr} x A$ mutants and to reduce insulin.

\section{METHODS}

Bacterial strains. Genotypes of the strains used are: $E$. coli $\mathrm{JM} 109$, end $A 1 \operatorname{rec} A 1$ gyr $A 96$ thi bsd $17\left(\mathrm{r}_{\mathrm{K}}^{-} \mathrm{m}_{\mathrm{K}}^{+}\right)$rel $A 1$ supE44 $\Delta($ lac-pro $A B)\left(\mathrm{F}^{\prime}\right.$ traD 36 pro $A B$ lac $\left.I^{\mathrm{q}} \mathrm{Z} \Delta \mathrm{M} 15\right) ;$ E. coli $\mathrm{BH} 5262$, $\mathrm{K} 12 \mathrm{~F}^{-}$araD139? galU galK bsdR rpsL argH1 trx $A 7004$ gsh $A$ srl:: Tn10; E. coli $\mathrm{BH} 2012, \mathrm{~K} 12 \mathrm{~F}^{-}$araD 139? galU galK bsdR rpsL met $A 46$ argH1 trx A7004 ilvC:: Tn5 (Lim et al., 1985); E. coli JF510 (Lim et al., 1986) is an $i l v C:: \operatorname{Tn} 5 \operatorname{tr} x A 7004$ derivative of strain $71 / 18\left[\Delta(\right.$ lac-pro $A B)$ thi supE $\left(\mathrm{F}^{\prime}\right.$ pro $A B$ lac $I^{\mathrm{q}}$ lacZ $\Delta \mathrm{M} 15)]$ (Heidecker et al., 1980). The above strains and phage T7 were kindly donated by J. A. Fuchs. E. coli MC1061 $\left[\mathrm{K} 12 \mathrm{~F}^{-}\right.$araD139? galU galK bsdR rpsL $\Delta($ ara $A B C-l e u) 7679$ $\Delta l a c X 74]$ was a gift from B. C. Persson.

Media. Tetrathionate medium was made from mineral salts solution $\left(\mathrm{g} \mathrm{l}^{-1}\right):\left(\mathrm{NH}_{4}\right)_{2} \mathrm{SO}_{4}, 3.0 ; \mathrm{KCl}, 0.1 ; \mathrm{K}_{2} \mathrm{HPO}_{4}, 0.5$; $\mathrm{Ca}\left(\mathrm{NO}_{3}\right)_{2}, 0.01$; the $\mathrm{pH}$ was adjusted to 2.5 with $\mathrm{H}_{2} \mathrm{SO}_{4}$ and it was autoclaved. Trace elements solution was $\left(\mathrm{mg} \mathrm{l}^{-1}\right)$ : $\mathrm{FeCl}_{3} .6 \mathrm{H}_{2} \mathrm{O}, 11.0 ; \quad \mathrm{CuSO}_{4} .5 \mathrm{H}_{2} \mathrm{O}, 0.5 ; \mathrm{HBO}_{3}, 2.0$; $\mathrm{Na}_{2} \mathrm{MoO}_{4} .2 \mathrm{H}_{2} \mathrm{O}, 0.8 ; \mathrm{CoCl}_{2} .6 \mathrm{H}_{2} \mathrm{O}, 0.6 ; \mathrm{ZnSO}_{4} .7 \mathrm{H}_{2} \mathrm{O}, 0.9$; filter sterilized. One millilitre trace elements solution was added to $100 \mathrm{ml}$ mineral salts solution and to this was added either $50 \mathrm{mM} \mathrm{K}_{2} \mathrm{~S}_{4} \mathrm{O}_{6}$ or $100 \mathrm{mM} \mathrm{FeSO}$, and the final $\mathrm{pH}$ was adjusted to $2 \cdot 5$.

Cloning and genetic manipulations. A cosmid bank of the $T$. ferrooxidans genome was constructed by cloning sized (36-45 kb) fragments, generated by partial digestion with Sau3AI into the BamHI restriction site of cosmid pHC79 (Ramesar, 1988). The bank was transduced into the $E$. coli mutant BH5262 according to the method of Sambrook et al. (1989). Possible thioredoxin-positive clones were identified by their ability to grow on M9 minimal medium (Sambrook et al., 1989). Strain $\mathrm{BH} 5262$ is unable to grow on minimal medium lacking in glutathione whereas $\operatorname{TrxA}{ }^{+}$or $\mathrm{GshA}^{+}$colonies can grow (Lim et al., 1986). E. coli strain BH2012 was used to confirm the $\operatorname{Trx} \mathrm{A}^{+}$ phenotype, as this methionine auxotroph is unable to synthesize methionine from methionine sulfoxide in the absence of a functional thioredoxin. Positive clones were re-transformed into E. coli $\mathrm{BH} 2012$ and cosmids were isolated from colonies able to grow on minimal medium plus methionine sulfoxide. Subclones of one of the $\operatorname{TrxA}{ }^{+}$cosmids were made and tested for the ability to complement $E$. coli strains BH2012 and BH5262.

DNA techniques, sequencing and analysis. Standard methods were used for plasmid preparation, restriction enzyme digests, gel electrophoresis, ligations and Southern blot hydridizations (Sambrook et al., 1989). Labelling of probes, hybridization and detection were done with the digoxygenin-dUTP non-radioactive DNA labelling and detection kit (Boehringer Mannheim). DNA sequencing was by the dideoxy chain-termination method (Sanger et al., 1977), using the Sequenase version 2.0 kit (USB).
The sequence of the $1.1 \mathrm{~kb}$ HindIII-PstI fragment from pTRX32 (Fig. 3) was determined from both strands. The Genetics Computer Group (GCG) software package was used for sequence analysis (Devereux et al., 1984).

In vitro synthesis of thioredoxin. The synthesis of polypeptides from cosmid 32, plasmids pTRX32, pTRX6, pTRX14A, pTRX9 and pBluescript SK was determined using the prokaryotic DNA-directed transcription kit, E. coli S30 system from Promega. Reactions were performed according to the manufacturer's specifications and the proteins were separated by SDS-PAGE using 10-20\% (w/v) gradient gels.

Phage growth. A growth curve of phage T7 was determined in E. coli host strains MC1061, BH2012 and BH2012(pTRX6). Phage titres were estimated using E. coli MC1061 as the plating bacterium, at different time intervals during the growth curve. Growth of phage M13 was monitored in E. coli strains $71 / 18$, JF510 and JF510(pTRX6). Cultures were inoculated with M13 phage to $5 \times 10^{8}$ p.f.u. $\mathrm{ml}^{-1}$ and grown overnight with vigorous aeration at $37^{\circ} \mathrm{C}$. The cultures were titred for M13 phage using E. coli $71 / 18$ as the plating bacterium, at the time of inoculation and again $20 \mathrm{~h}$ later.

Insulin assay. The insulin assay of Holmgren (1979) was used to measure the rate of disulfide reduction, by recording the rate of precipitation at $650 \mathrm{~nm}$. Crude cell extracts were prepared as follows. Mid-exponential phase bacterial cells were harvested from $100 \mathrm{ml}$ minimal medium and resuspended in $1 \mathrm{ml}$ assay buffer (100 mM potassium phosphate, $\mathrm{pH} 7 \cdot 5,1 \mathrm{mM}$ EDTA, $1 \mathrm{mM}$ DTT and $1 \mathrm{mM}$ Pefabloc). Pefabloc [4-(2-aminoethyl)benzenesulfonyl fluoride hydrochloride] was from Boehringer Mannheim. After sonication, lysed cells were precipitated and the supernatant was heated at $85^{\circ} \mathrm{C}$ for $5 \mathrm{~min}$. Denatured proteins were removed by centrifugation and the supernatant was used in the assay. Insulin was added to $900 \mu$ crude extract (final concentration $1 \mathrm{mg} \mathrm{ml}^{-1}$ ), the reaction was initiated by adding $3 \mu \mathrm{l} 100 \mathrm{mM}$ DTT and monitored by measuring the increase in optical density at $650 \mathrm{~nm}$ (Beckman DU64 spectrometer). Crude extract prepared from $E$. coli BH2012 $\operatorname{tr} x A$ mutant was used as a negative control.

Analysis of transcripts. T. ferrooxidans total RNA was prepared from cultures grown on tetrathionate medium, and E. coli total RNA from cultures grown on M9 minimal medium, by the method of Aiba et al. (1981). For DNA: RNA hybridization blots, total RNA was separated on a $1.5 \%(w / v)$ agarose gel containing $6 \%(\mathrm{v} / \mathrm{v})$ formaldehyde. The RNA was transferred to an Amersham Hybond $\mathrm{N}^{+}$membrane and hybridization and washes were carried out according to the manufacturer's protocol. The HindIII fragment of pTRX9, labelled with [ $\alpha-$ $\left.{ }^{32} \mathrm{P}\right] \mathrm{dCTP}$, using a Random Primed DNA labelling kit from Boehringer Mannheim, was used as a probe. Transcript starts were determined by primer-extension analysis. A synthetic $27 \mathrm{bp}$ DNA oligomer primer was end-labelled using the polynucleotide kinase $/\left[\gamma_{-}{ }^{32} \mathrm{P}\right]$ method (Ausubel et al., 1993), and hybridized to the $5^{\prime}$ end of the thioredoxin mRNA. Primer extension was carried out using total RNA derived from $E$. coli BH5262(pTRX6) and total RNA from T. ferrooxidans according to the method of Ausubel et al. (1993).

\section{RESULTS}

\section{Isolation and localization of the $T$. ferrooxidans thioredoxin gene}

Transduction of the $T$. ferrooxidans genome cosmid library into $E$. coli $\mathrm{BH} 5262$ resulted in approximately 100 colonies that were able to grow on minimal medium lacking 


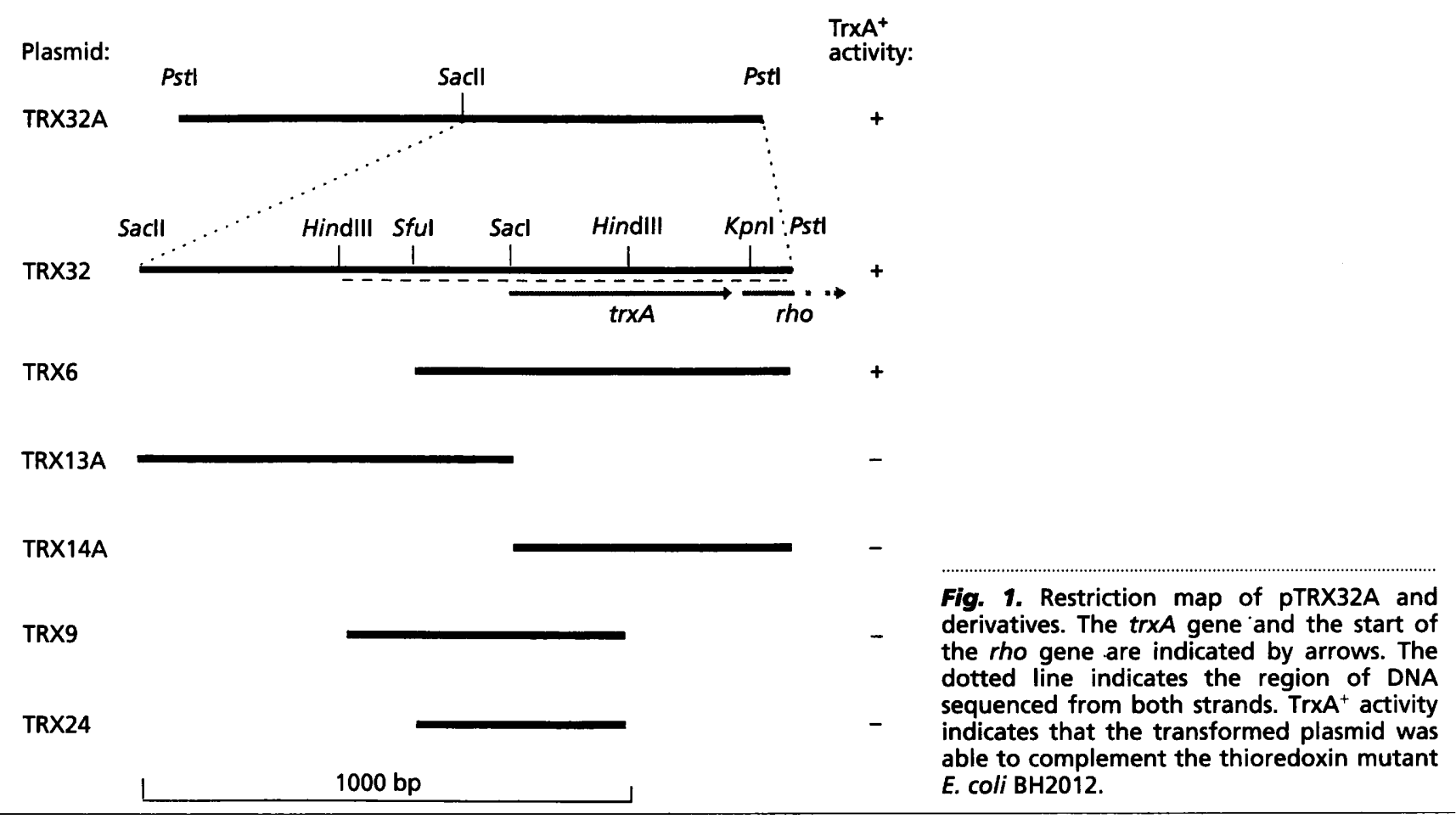

glutathione. DNA was prepared from 16 of these colonies. These cosmids had several fragments in common and could be divided into two groups that appeared to contain overlapping pieces of two regions of the $T$. ferrooxidans chromosome. Only one of the groups of cosmids, on transforming into E. coli $\mathrm{BH} 2012$, enabled cells to grow on minimal medium plus methionine sulfoxide. One cosmid from this group, containing a $37 \mathrm{~kb}$ genomic insert (cosmid 32), was chosen for further study.

Pst I fragments from cosmid 32 were cloned into the vector pBluescript SK and tested for complementation of E. coli BH5262, resulting in subclone pTRX32A. A restriction map of pTRX32A was constructed and smaller fragments were subcloned into pBluescript SK (Fig. 1). Plasmids pTRX32 and pTRX6 complemented E. coli mutants BH5262 and BH2012, while plasmids pTRX13A, pTRX14A and pTRX9 did not, indicating that the thioredoxin gene was located between the SfuI and Pst I sites of PTRX32.

The source of the cloned thioredoxin-complementing DNA was confirmed by hybridization of the labelled SacI$K p n \mathrm{I}$ fragment from pTRX32 to T. ferrooxidans ATCC33020 chromosomal DNA, cosmid 32, pTRX32 and pTRX6 (Fig. 2). The $685 \mathrm{bp}$ HindIII fragment that is internal to the cloned T. ferrooxidans chromosomal DNA present on pTRX32 corresponded exactly to a HindIII fragment present on the $T$. ferrooxidans chromosome, cosmid 32 and pTRX32. The hybridization signal at $1.8 \mathrm{~kb}$ represents the adjacent HindIII fragment which contains part of the $\operatorname{tr} x A$ and $r b o$ genes and is present in the chromosomal and the cosmid DNA only. Similarly, when the T. ferrooxidans chromosomal DNA was digested with both $S a c I$ and $K p n I$, a single 530 bp hybridization

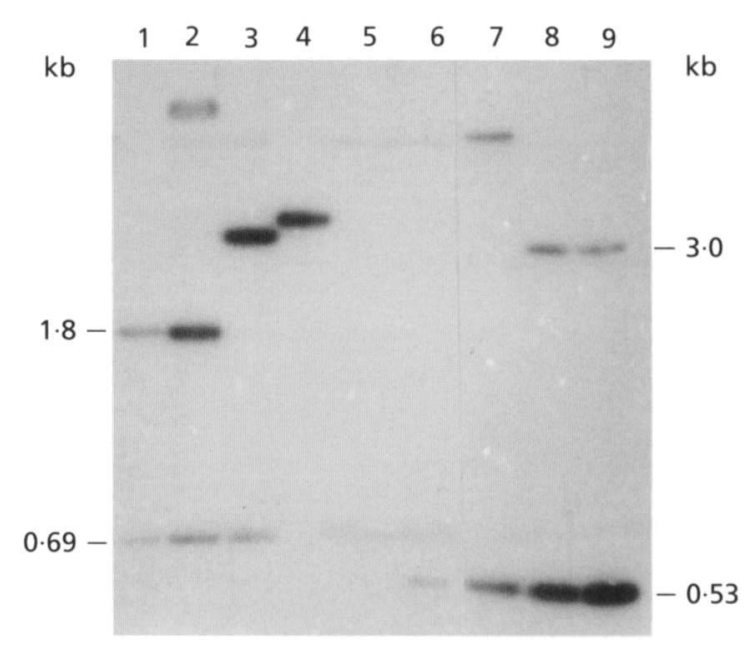

Fig. 2. Hybridization of the labelled 517 bp Kpnl-Sacl fragment of pTRX32 to HindIII digests (lanes 1-4) and Kpnl-Sacl digests (lanes 6-9) of: lanes 1 and 6, T. ferrooxidans chromosomal DNA; lanes 2 and 7, cosmid 32; lanes 3 and 8, pTRX32; lanes 4 and 9, pTRX6. Lane 5, blank.

signal, which was also present on cosmid 32, pTRX32 and pTRX 6 was detected. This indicated that the source of the cloned gene originated from T. ferrooxidans A TCC 33020 and that there was only one copy of the thioredoxin gene per genome. Over-exposure of the autoradiogram (not shown) failed to indicate any additional chromosomal bands. The faint upper bands in lanes 2, 7, 8 and 9 (Fig. 2) are due to a low concentration of vector DNA which remained in the incompletely purified $S a c \mathrm{I}-K p n \mathrm{I}$ probe. 


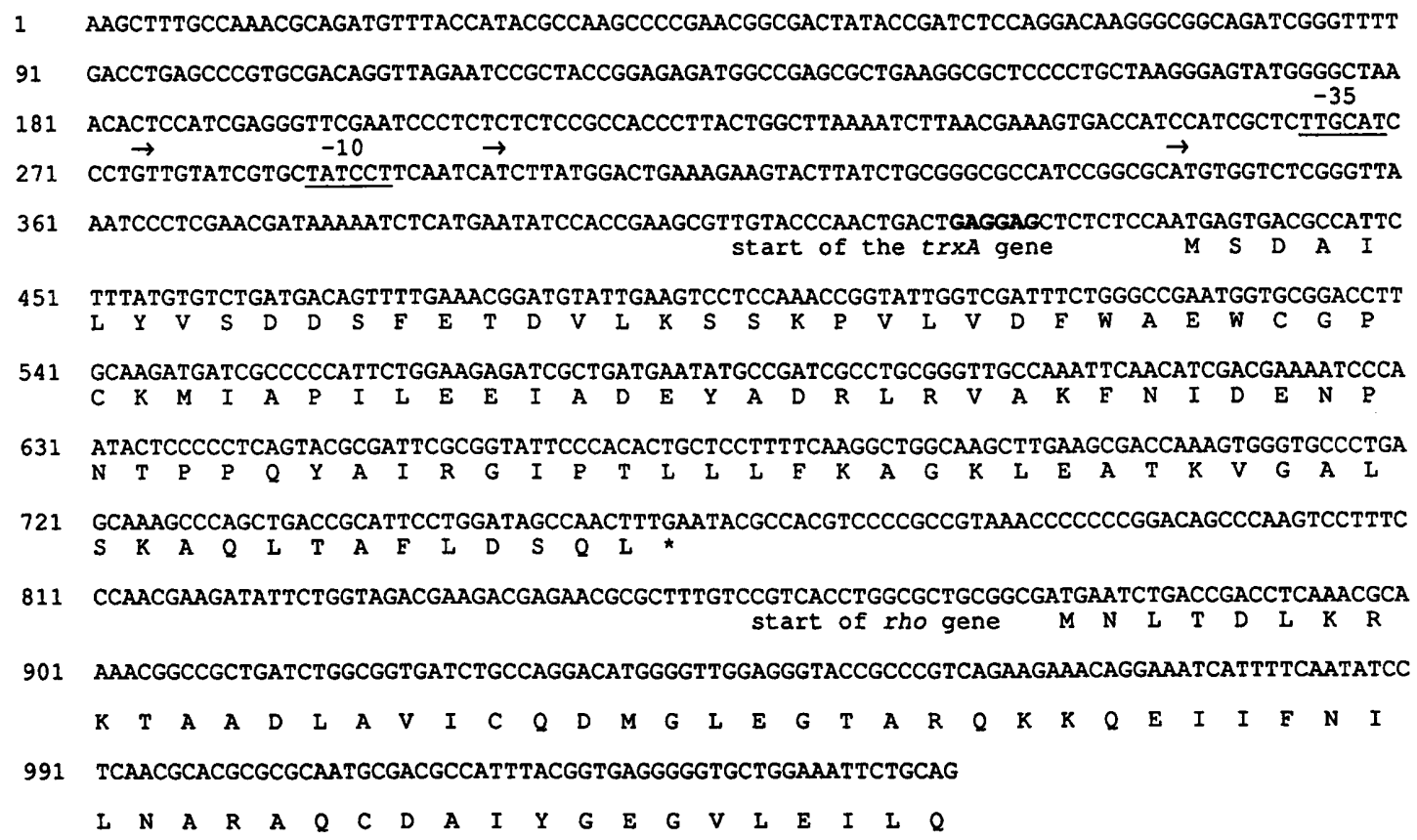

Fig. 3. Nucleotide and deduced amino acid sequence of the HindllI-Pstl fragment of pTRX32A, containing the trxA gene and the $\mathrm{N}$-terminal region of the rho gene. A putative RBS is located in bold and the -10 and -35 regions of a $\sigma^{70}$-like promoter are underlined; 5' transcription start sites are indicated by arrows.

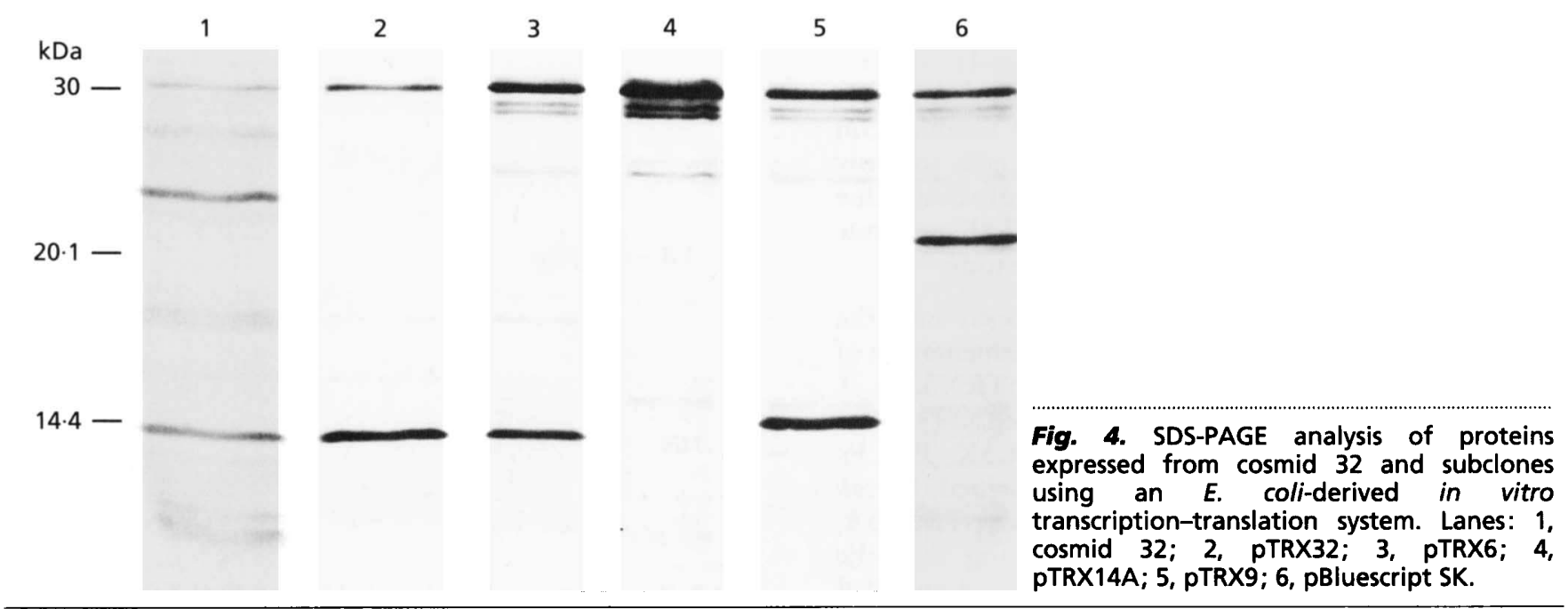

\section{Sequence analysis}

Analysis of the sequence data revealed one complete and one partial ORF (Fig. 3). The complete ORF is preceded by a strong RBS and encodes a protein of 101 amino acids, corresponding to a polypeptide of $11.2 \mathrm{kDa}$. The predicted amino acid sequence was closely related to thioredoxins from other prokaryotic and eukaryotic organisms and contains the highly conserved active site sequence, -Trp-Cys-Gly-Pro-Cys- (Holmgren, 1968). T. ferrooxidans thioredoxin was most similar to the $E$. coli ( $71 \%$ identity, GenBank/EMBL accession no. M12779) and Chromatium vinosum (70\% identity, accession no. P09857) thioredoxins and least similar to the thioredoxins from Dictyostelium discoideum (56\% identity, accession no. M91384) and Saccharomyces cerevisiae (56\% identity, accession no. M62647). An incomplete ORF was situated 126 bp downstream of the thioredoxin gene in pTRX32 and although there is no clear RBS, the predicted polypeptide has similarity to the rho termination protein of other prokaryotes. Only the first 58 amino acids of the predicted $T$. ferrooxidans rho protein were analysed and this sequence shows clear similarity (59\% identity, accession no. J01673) to the E. coli rho protein.

Synthesis of a protein corresponding to the $T$. ferrooxidans thioredoxin was confirmed using an E. coli-derived in vitro transcription-translation system. A protein of approxi- 
Table 1. Growth of phages $T 7$ and $M 13$ in different hosts

Values are expressed as p.f.u. $\mathrm{ml}^{-1}$. Data are the means of three different experiments \pm sD.

\begin{tabular}{|c|c|c|c|c|c|}
\hline \multirow[t]{2}{*}{ Phage } & \multirow[t]{2}{*}{ E. coli host strain } & \multicolumn{4}{|c|}{ Time (min) } \\
\hline & & 0 & 120 & 180 & 1200 \\
\hline \multirow[t]{3}{*}{$\mathrm{T} 7$} & MC1061 & $1.26 \pm 0.60 \times 10^{8}$ & $3.16 \pm 1.97 \times 10^{10}$ & $5.01 \pm 0.50 \times 10^{10}$ & - \\
\hline & BH2012(pTRX6) & $1.58 \pm 0.64 \times 10^{8}$ & $1.00 \pm 1.24 \times 10^{10}$ & $1.58 \pm 1.20 \times 10^{10}$ & - \\
\hline & BH 2012 & $1.58 \pm 1.00 \times 10^{8}$ & $1 \cdot 26 \pm 3.27 \times 10^{8}$ & $1 \cdot 26 \pm 2.42 \times 10^{8}$ & - \\
\hline \multirow[t]{3}{*}{ M13 } & $71 / 18$ & $1.69 \pm 0.13 \times 10^{8}$ & - & - & $1.71 \times 0.51 \times 10^{11}$ \\
\hline & JF510(pTRX6) & $1.55 \pm 0.39 \times 10^{8}$ & - & - & $2.63 \times 1.38 \times 10^{8}$ \\
\hline & JF510 & $1.52 \pm 0.45 \times 10^{8}$ & - & - & $1.45 \pm 1.03 \times 10^{8}$ \\
\hline
\end{tabular}

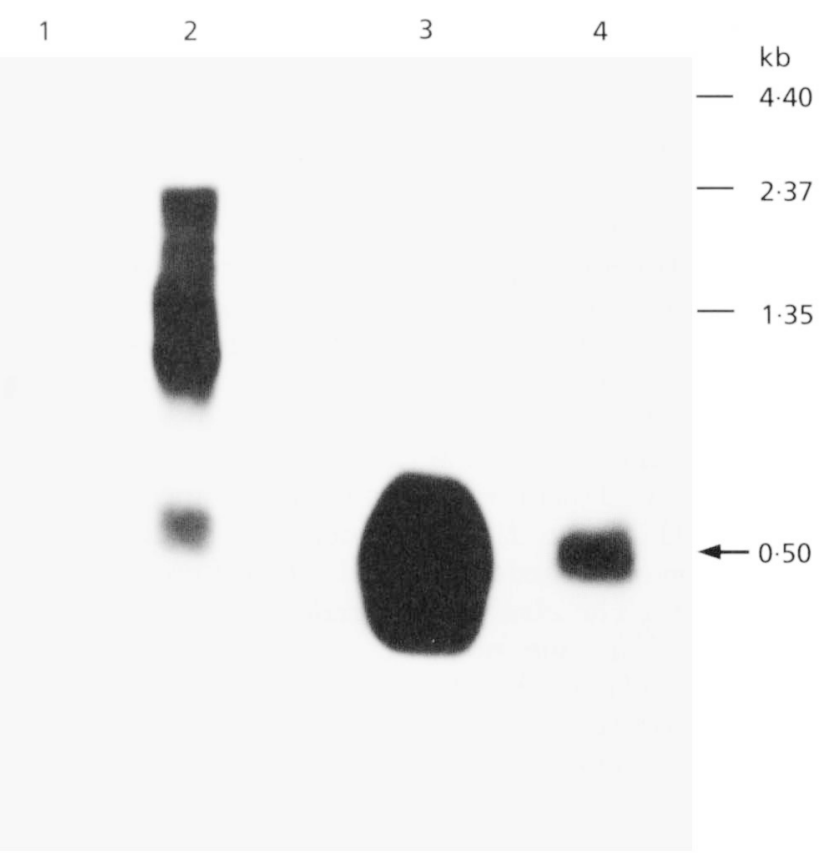

Fig. 5. Hybridization of labelled HindIII fragment of pTRX9 to total RNA prepared from: lane 1, E. coli BH5262 ( $20 \mu \mathrm{g})$; lane 2, E. coli BH5262(pTRX6) $(\sim 40 \mu \mathrm{g})$; lane 3, T. ferrooxidans $(\sim 25 \mu \mathrm{g})$; lane $4, T$. ferrooxidans $(\sim 5 \mu \mathrm{g})$.

mately $14 \mathrm{kDa}$ was produced by cosmid 32 and plasmids pTRX6, pTRX32 but not by pTRX14A, nor the vector pBluescript SK (Fig. 4). A slightly larger protein was synthesized from plasmid pTRX9 (Fig. 4, lane 5), but this construct lacks the stop codon of the thioredoxin gene, so the larger protein is probably the result of transcriptional read-through.

\section{T7 and M13 phage complementation}

The ability of the T. ferrooxidans thioredoxin expressed from pTRX6 in E. coli BH2012 to support phage T7 replication was compared with the thioredoxin expressed from the chromosome of the E. coli parental strain MC1061 (Table 1). Titres of phage T7 reached almost the same level when the $T$. ferrooxidans thioredoxin was provided as the titre obtained with the natural E. coli thioredoxin. When E. coli strain BH2012(pTRX6) was used as the plating bacterium, the phage T7 plaques were more variable in size and slightly smaller than when strain MC1061 was used. The cloned T. ferrooxidans $\operatorname{tr} x A$ gene was clearly able to complement the $E$. coli $\mathrm{BH} 2012 \operatorname{tr} x A$ mutant to support growth of phage T7 although with a slightly reduced efficiency. The $T$. ferrooxidans thioredoxin, therefore, appears to be able to form a functional association with the gene 5 protein of the phage T7 DNA polymerase complex.

The ability of the $T$. ferrooxidans thioredoxin to support the growth of phage M13 is shown in Table 1. Although there was a slight increase in the titre of phage M13 in $E$. coli JF510(pTRX6) relative to the E. coli JF510 control when grown in liquid medium, no plaques were detected on solid medium when JF510(pTRX6) was used as the plating bacterium. The $T$. ferrooxidans thioredoxin was not able to satisfy the thioredoxin requirement of the filamentous phage.

\section{Insulin reduction}

Thioredoxin has been shown to catalyse the reduction of the insulin disulfide bridge by dithiothreitol (Holmgren, 1979). This reduction results in the precipitation of the insulin B chain which can be readily measured as an increase in optical density. We compared crude extracts of E. coli $\operatorname{tr} x A$ mutants with and without the cloned $T$. ferrooxidans $\operatorname{trx} A$ gene for the ability to reduce insulin. Extracts prepared from E. coli BH2012(pTRX6) cells were able to reduce insulin at a greatly enhanced rate compared to extracts from E. coli $\mathrm{BH} 2012$ cells (results not shown). This clearly indicates that the thioredoxin from the cloned $T$. ferrooxidans trx $A$ gene was active in $E$. coli.

\section{Transcript analysis}

To determine whether the $T$. ferrooxidans $\operatorname{tr} x A$ gene was independently transcribed, or was co-transcribed with an unidentified upstream gene or with the downstream rbo gene, DNA:RNA hybridization analysis was carried out on RNA transcripts prepared from E. coli BH5262 trxA mutants, E. coli BH5262(pTRX6) and T. ferrooxidans cells and probed with the HindIII fragment from pTRX9 (Fig. 


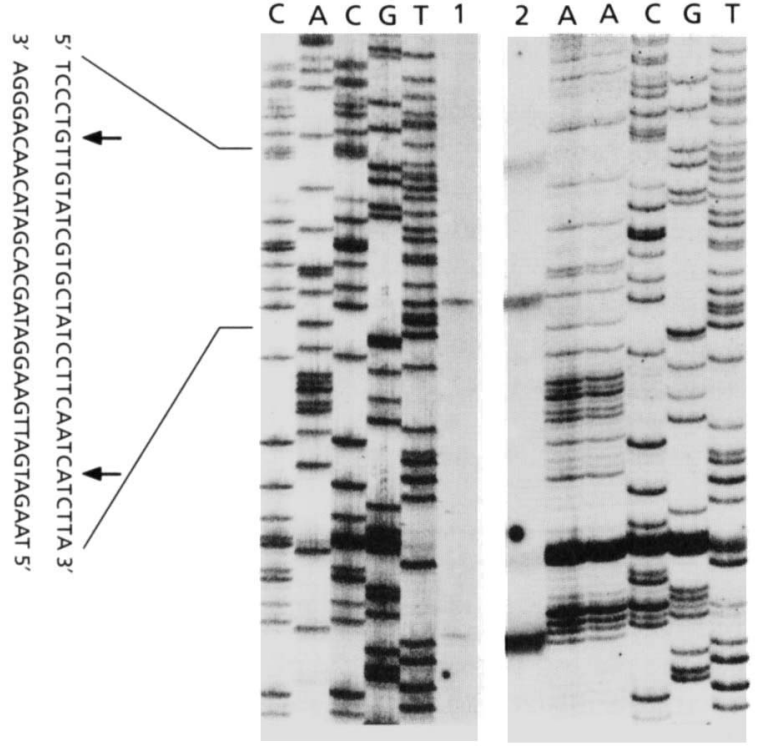

Fig. 6. Primer-extension analysis of the $5^{\prime}$ transcription start sites of the trxA gene cloned in $E$. coli and in $T$. ferrooxidans. The letters above each lane indicate the dideoxynucleotide used to terminate the sequencing reaction. Extension products from E. coli BH5262(pTRX6) (lane 1) and T. ferrooxidans (lane 2) RNA. The first two transcription start sites of the gene in $T$. ferrooxidans are indicated by arrows.

1). A single transcript of about $0.5 \mathrm{~kb}$ was obtained for RNA from $T$. ferrooxidans cells (Fig. 5, lanes 3 and 4), which would correspond to the predicted size of the thioredoxin gene and indicate that the $T$. ferrooxidans $\operatorname{tr} x A$ gene is transcribed on its own. Several transcripts were produced from E. coli BH5262(p'TRX6) cells (Fig. 5, lane 2 ) and one of these corresponded exactly in size to the $0.5 \mathrm{~kb}$ signal from $T$. ferrooxidans, while the other transcripts were much larger (approximate sizes 1·35, 1.4, 1.6 and $1.8 \mathrm{~kb}$ ). These presumably represent transcription products that originate from the lac $Z$ promoter of the vector. A very weak signal at about $0.45 \mathrm{~kb}$ was produced from RNA isolated from E. coli $\mathrm{BH} 5262$ cells which was smaller in size than the $T$. ferrooxidans trx $A$ transcript and may represent a low amount of $\operatorname{tr} x A$ transcription from the E. coli BH5262 trxA mutant.

Primer-extension analysis was used to compare the transcriptional start sites of the $T$. ferrooxidans $\operatorname{tr} x A$ gene in its natural host with those of the gene cloned in E. coli. RNA prepared from $T$. ferrooxidans gave three possible transcriptional start sites, at positions 274,298 and 345 (see Fig. 6, lane 2). In the case of RNA from E. coli BH5262(pTRX6), only two transcription start sites were detected which were identical to those of $T$. ferrooxidans at positions 298 and 345 (Fig. 6, lane 1).

\section{DISCUSSION}

As an obligately autotrophic, chemolithotrophic and acidophilic bacterium, $T$. ferrooxidans has a unique physiology and occupies a very different ecological niche compared with E. coli. Based on 16S rRNA sequences, $T$. ferrooxidans is grouped with the $\beta$-protobacteria (Lane $e t$ al., 1992), whereas E. coli is a $\gamma$-protobacterium. In spite of these differences, the two bacteria share a remarkable amount of similarity at the genetic level (Rawlings \& Kusano, 1994). Analysis of the $\operatorname{tr} x A$ genes and flanking regions is an illustration of this. In both bacteria, the $\operatorname{tr} x A$ genes are independently transcribed (Wallace \& Kushner, 1984), present in a single copy and have a rho gene located immediately downstream. Furthermore, two of the three $\operatorname{trx} A$ transcriptional start sites detected in $T$. ferrooxidans were also functional in E. coli. A minor difference is that in E. coli approximately $10 \%$ of the rbo gene mRNA occurs as a $2.1 \mathrm{~kb}$ transcript (Matsumoto et al., 1986), which is a result of transcriptional read-through from the $\operatorname{trx} A$ gene. This does not appear to be the case in $T$. ferrooxidans.

The $T$. ferrooxidans thioredoxin was clearly functional in $E$. coli as it enabled the growth of the E. coli B 5262 gsh $A$ $\operatorname{tr} x A$ mutant on minimal medium lacking glutathione and the E. coli $\mathrm{BH} 2012$ trx $A$ met mutant to reduce methionine sulfoxide to methionine. The ability of the $T$. ferrooxidans thioredoxin in E. coli to support growth of phage T7, but not the filamentous phage M13, is different to what was found with the thioredoxin from Anabaena sp. strain PCC7119. No growth of wild-type phage T7 occurred in the presence of the Anabaena thioredoxin, indicating that it was unable to form an active DNA polymerase complex with the gene 5 protein in vitro (Lim et al., 1986). It has been suggested that the regions around amino acids 74-77 and $91-93$ of the E. coli protein are critical for the interaction of thioredoxin with the gene 5 protein (Huber et al., 1986). The Anabaena thioredoxin differs by a single amino acid in one of these regions (E. coli G74 to Anabaena S74), whereas the T. ferrooxidans thioredoxin is identical to that of E. coli. This may explain why the $T$. ferrooxidans thioredoxin can support the growth of phage T7 whereas the Anabaena thioredoxin failed to do so.

\section{ACKNOWLEDGEMENTS}

We thank James Fuchs, for E. coli strains JF510, BH5262 and BH2012, Britt C. Persson for E. coli strain MC1061 and phage T7, Di James for assistance with sequencing and Arne Holmgren for helpful discussions. This work was supported by grants from the Foundation for Research Development and Gencor (South Africa).

\section{REFERENCES}

Aiba, H., Adhaya, S. \& de Crombrugge, B. (1981). Evidence for two functional gal promoters in intact Escherichia coli cells. $J$ Biol Chem 256, 11905-11910.

Ausubel, F. M., Brent, R., Kingston, R. E., Moore, D. D., Seidman, J. G., Smith, J. A. \& Struhl, K. (1993). Current Protocols in Molecular Biology. New York: Wiley Interscience.

Buchanan, B. B. (1980). Role of light in the regulation of chloroplast enzymes. Annu Rev Plant Physiol 31, 341-374.

Buchanan, B. B., Wolosuik, R. A. \& Schurmann, P. (1979). Thioredoxin and enzyme regulation. Trends Biochem Sci 4, 93-96.

Carlin, A., Shi, W., Dey, S. \& Rosen, B. P. (1995). The ars operon of Escherichia coli confers arsenical and antimonial resistance. J Bacteriol 177, 981-986. 
Devereux, J., Haeberli, P. \& Smithies, O. (1984). A comprehensive set of sequence analysis programs for the VAX. Nucleic Acids Res 12, 387-395.

Gonzalez Porqué, P., Baldesten, A. \& Reichard, P. (1970). The involvement of the thioredoxin system in reduction of methionine sulfoxide and sulfate. $J$ Biol Chem 245, 2371-2374.

Heidecker, G., Messing, J. \& Groneneborn, B. (1980). A versatile primer for DNA sequencing in the M13mp2 cloning system. Gene 10, 69-73.

Holmgren, A. (1968). Thioredoxin 6. The amino acid sequence of the protein from Escherichia coli B. Eur J Biochem 6, 475-484.

Holmgren, A. (1979). Thioredoxin catalyzes the reduction of insulin disulfides by dithiothreitol and dihydrolipoamide. $J$ Biol Chem 254, 9627-9632.

Holmgren, A. (1989). Thioredoxin and glutaredoxin systems. J Biol Chem 264, 13963-13966.

Huber, H. E., Russel, M., Model, P. \& Richardson, C. C. (1986). Interaction of mutant thioredoxins of Eschericbia coli with the gene 5 protein of phage T7. J Biol Chem 261, 15006-15012.

Ji, G. \& Silver, S. (1992). Reduction of arsenate to arsenite by the ArsC protein of the arsenic resistance operon of Staphylococcus aureus plasmid pI258. Proc Natl Acad Sci US A 89, 9474-9478.

Kusano, T., Takeshima, T., Inoue, C. \& Sugawara, K. (1991). Evidence for two sets of structural genes for ribulose bisphosphate carboxylase in Thiobacillus ferrooxidans. J Bacteriol 173, 7313-7323.

Lane, D. J., Harrison, A. P., Stahl, D., Jr, Pace, B., Giovannoni, S. J., Olsen, G. J. \& Pace, N. R. (1992). Evolutionary relationships among sulfur- and iron-oxidizing eubacteria. $J$ Bacteriol 174, 269-278.

Laurent, T. C., Moore, E. C. \& Reichard, P. (1964). Enzymatic synthesis of deoxyribonucleotides. IV. Isolation and characterization of thioredoxin, the hydrogen donor from Escherichia coli B. $J$ Biol Chem 239, 3436-3444.

Lim, C.-J., Geraghty, D. \& Fuchs, J. A. (1985). Cloning and nucleotide sequence of the $\operatorname{tr} x A$ gene of Escherichia coli $\mathrm{K}-12 . J$ Bacteriol 163, 311-316.
Lim, C.-J., Gleason, F. K. \& Fuchs, J. A. (1986). Cloning, expression and characterization of the Anabaena thioredoxin gene in Escherichia coli. J Bacteriol 168, 1258-1264.

Mark, D. \& Richardson, C. C. (1976). Escherichia coli thioredoxin: a subunit of bacteriophage T7 DNA polymerase. Proc Natl Acad Sci US A 73, 780-784.

Matsumoto, Y., Shigesada, K., Hirano, M. \& Imai, M. (1986). Autogenous regulation of the gene for transcriptional termination factor Rho in Escherichia coli: localization and function of its attenuators. $J$ Bacteriol 166, 945-958.

Moore, E. C., Reichard, P. \& Thelander, L. (1964). Enzymatic synthesis of deoxyribonucleotides. V. Purification and properties of thioredoxin reductase from Escherichia coli. $J$ Biol Chem 239, 3445-3452.

Ramesar, R. S. (1988). Developmental genetic studies on Thiobacillus ferrooxidans. PhD thesis, University of Cape Town.

Rawlings, D. E. \& Kusano, T. (1994). Molecular genetics of Thiobacillus ferrooxidans. Microbiol Rev 58, 39-55.

Russel, M. \& Model, P. (1986). The role of thioredoxin in filamentous phage assembly. J Biol Chem 261, 14997-15005.

Sambrook, J., Fritsch, E. F. \& Maniatis, T. (1989). Molecular Cloning: a Laboratory Manual, 2nd edn. Cold Spring Harbor, NY: Cold Spring Harbor Laboratory.

Sanger, F., Nicklen, S. \& Coulson, A. R. (1977). DNA sequencing with chain-terminating inhibitors. Proc Natl Acad Sci USA 74, 5463-5467.

Tabor, S., Huber, H. E. \& Richardson, C. C. (1987). Eschericbia coli thioredoxin confers processivity on the DNA polymerase activity of the gene 5 protein of bacteriophage T7. J Biol Cbem 262, 16212-16223.

Wallace, B. J. \& Kushner, S. R. (1984). Genetic and physical analysis of the thioredoxin $(\operatorname{tr} x A)$ gene of Escherichia coli K-12. Gene 32, 399-408.

Received 6 January 1995; revised 17 April 1995; accepted 12 May 1995. 